\title{
ОСВІТНЬО-НАУКОВА ПРОГРАМА ЗА СПЕЦІАЛЬНІСТЮ 091 «БІОЛОГІЯ»
}

\author{
Л. Ю. Бабінцева, Н. Г. Горовенко, І. В. Дзюблик, \\ Д. Л. Кирик, С. О. Соловйов, С. В. Подольська
} Національний університет охорони здоров'я України імені П. Л. Шупика

\begin{abstract}
Біологія — напрям, котрий є трансдисциплінарною галуззю знань та розглядається як комплекс наукових дисциплін, що вивчають живі організми, їх будову, функціонування, поширення, походження та розвиток, а також природні співтовариства організмів, їх зв'язки один із одним, із неживою природою та людиною. Представлено сучасне бачення навчання майбутніх спеціалістів ступеня доктора філософії за спеціальністю 091 «Біологія» галузі знань 09 «Біологія». Сучасна біологія має декілька особливостей: вивчення взаємозв'язку біологічного та соціального розвитку людини; щільний зв'язок із низкою високотехнологічних напрямів, що включають молекулярну біологію, молекулярну генетику, системну біомедицину. Практично всі нові напрями та особливості пов'язані 3 використанням інорормаційних технологій.

По завершенню навчання, здобувачі вищої освіти третього рівня мають оволодіти загальнонауковими компетентностями, здобути універсальні навики дослідника та мовні компетентності. Тематика курсів професійної підготовки розроблена 3 метою сприяння здатності інтегрувати знання та розв'язувати складні завдання в мультидисциплінарних і трансдисциплінарних контекстах. Отже, зміст запропонованої освітньо-наукової програми за спеціальністю 091 «Біологія» спрямовано на підготовку висококвалісрікованих і конкурентоспроможних спеціалістів ступеня доктора фрілософії та здобуття ними в процесі навчання необхідних теоретичних знань, що носять мультидисциплінарний характер, та комплексу практичних умінь, навиків і компетентностей для виконання інноваційних наукових досліджень та впровадження отриманих результатів у практичну охорону здоров'я.
\end{abstract}

Ключові слова: освітньо-науковапрограма, біологія, здобувач вищої освіти, компетентність, мульдисциплінарність, трансдисциплінарність.

\section{EDUCATIONAL-SCIENTIFIC PROGRAM BY SPECIALTY 091 «BIOLOGY»}

\author{
L. Yu. Babintseva, N. G. Gorovenko, I. V. Dziublyk, \\ D. L. Kyryk, S. O. Soloviov, S. V. Podolska \\ Shupyk National Healthcare University of Ukraine
}

\begin{abstract}
Background. Biology is a field that is a transdisciplinary field of knowledge and is considered as a set of scientific disciplines that study living organisms, their structure, functioning, distribution, origin and development, as well as natural communities of organisms, their relationships with each other, with inanimate nature and man. The modern vision of training future specialists of the degree of Doctor of Philosophy in the specialty 091 «Biology» in the field of knowledge 09 «Biology» is presented.

Material and methods. Modern biology has several features: the study of the relationship between biological and social development of man; close connection with a number of high-tech areas, including molecular biology, molecular genetics, systems biomedicine. Virtually all new areas and features are related to the use of information technology.

Results. Upon completion of their studies, third-level higher education students must master general scientific (philosophical) competencies, acquire universal research skills and language competencies. The topics of the training courses are designed to promote the ability to integrate knowledge and solve complex problems in multidisciplinary and transdisciplinary contexts.

Conclusion. The content of the proposed educational-scientific program in specialty 091 «Biology» is aimed at training highly qualified and competitive specialists of the degree of Doctor of Philosophy, acquisition by them in the course of training of necessary theoretical knowledge and a complex of practical abilities, skills and competences to perform innovative research, also the implementation of the obtained results in practical health care.
\end{abstract}

Key words: educational-scientific program, biology, higher education, competence, multidisciplinarity, transdisciplinarity. 


\title{
ОБРАЗОВАТЕЛЬНО-НАУЧНАЯ ПРОГРАММА ПО СПЕЦИАЛЬНОСТИ 091 «БИОЛОГИЯ»
}

\author{
Л. Ю. Бабинцева, Н. Г. Горовенко, И. В. Дзюблик, \\ Д. Л. Кирик, С. А. Соловьев, С. В. Подольская \\ Национальный университет здравоохранения Украины имени П. Л. Шупика
}

\begin{abstract}
Биология - направление, являющееся трансдисциплинарной отраслью знаний и рассматривается как комплекс научных дисциплин, изучающих живые организмы, их строение, функционирование, распространение, происхождение и развитие, а также природные сообщества организмов, их связи друг с другом, с неживой природой и человеком. Представлено современное видение обучения будущих специалистов степени доктора фрилософии по специальности 091 «Биология» отрасли знаний 09 «Биология». Современная биология имеет несколько особенностей: изучение взаимосвязи биологического и социального развития человека; тесную связь с рядом высокотехнологичных направлений, включающих молекулярную биологию, молекулярную генетику, системную биомедицину. Практически все новые направления и особенности связаны с использованием инорормационных технологий.

По завершению обучения, соискатели высшего образования третьего уровня должны овладеть общенаучными компетентностями, получить универсальные навыки исследователя и языковые компетентности. Тематика курсов профессиональной подготовки разработана с целью содействия способности интегрировать знания и решать сложные задачи в мультидисциплинарных и трансдисциплинарных контекстах. Содержание предложенной образовательно-научной программы по специальности 091 «Биология» направлено на подготовку высококвалифицированных и конкурентоспособных специалистов степени доктора фрилососиии, получения ими в процессе обучения необходимых теоретических знаний, носящих мультидисциплинарный характер, и комплекса практических умений, навыков и компетентностей для выполнения инновационных научных исследований и внедрения полученных результатов в практическое здравоохранение.
\end{abstract}

Ключевые слова: образовательно-научная программа, биология, соискатель высшего образования, компетентность, мультидисциплинарность, трансдисциплинарность.

Вступ. Спеціальність 091 «Біологія» (міжнародна кодифікація 0511 Biology) - синтетичний науково-біологічний напрям, реалізація якого спрямована на здобуття компетентностей, необхідних навиків і знань відповідно до Національної рамки кваліфікацій, що в останні роки набуває великого соціального значення. Надшвидке зростання нових інформаційних технологій висуває перед здобувачами вищої освіти ступеня доктора філософії нове важливе завдання — обгрунтування методології застосування в практичній і науковій діяльності комплексу сучасних засобів, достатніх для продукування нових ідей, розв’язання комплексних проблем у галузі, а також самостійної науково-дослідницької, дослідницько-інноваційної, науково-організаційної, педагогічно-організаційної та практичної діяльності. До останнього часу єдиної уніфікованої платформи підготовки не запропоновано. Представлену освітньонаукову програму створено з метою виправити це становище. Гарант освітньо-наукової програми та голова проєктної групи - д. біол. н. доцент Л. Ю. Бабінцева, декан факультету підвищення кваліфікації викладачів.

\section{1. ПРОФІЛЬ ОСВІТНЬОЇ ПРОГРАМИ}

Галузь знань 09 «Біологія»

Спеціальність 091 «Біологія»

\section{1 - Загальна інформація}

\begin{tabular}{|l|l|}
\hline Тип освітньої програми & $\begin{array}{l}\text { Освітньо-наукова програма } \\
\text { третій (освітньо-науковий) рівень вищої освіти }\end{array}$ \\
\hline Обсяг освітньої програми & 60 кредитів ЄКТС (4 академічних роки) \\
\hline
\end{tabular}




\begin{tabular}{|c|c|}
\hline Ступінь вищої освіти & Доктор філософії \\
\hline $\begin{array}{l}\text { Офіційна назва } \\
\text { освітньої програми }\end{array}$ & Біологія \\
\hline $\begin{array}{l}\text { Повна назва закладу } \\
\text { вищої освіти та структурних } \\
\text { підрозділів, де здійснюється } \\
\text { навчання }\end{array}$ & $\begin{array}{l}\text { Національний університет охорони здоров’я України } \\
\text { імені П. Л. Шупика, } \\
\text { Факультет підвищення кваліфікації викладачів, } \\
\text { Український державний інститут репродуктології, } \\
\text { Медико-профілактичний та фармацевтичний факультет }\end{array}$ \\
\hline Цикл/рівень & $\begin{array}{l}\text { HРК України - } 8 \text { рівень, FQ-EHEA - третій цикл, } \\
\text { EQF-LLL - } 8 \text { рівень }\end{array}$ \\
\hline Мова викладання & українська \\
\hline Строк дії освітньої програми & 5 років \\
\hline Передумови & Ступінь магістра чи ОКР спеціаліста \\
\hline Форми навчання & очна (денна, вечірня), заочна \\
\hline $\begin{array}{l}\text { Інтернет-адреса постійного } \\
\text { розміщення опису освітньої } \\
\text { програми }\end{array}$ & https://nuozu.edu.ua/nv/vo/aspirantura-ta-doktorantura \\
\hline \multicolumn{2}{|r|}{2 - Мета освітньої програми } \\
\hline \multicolumn{2}{|c|}{$\begin{array}{l}\text { Підготовка висококваліфікованого, конкурентоспроможного, інтегрованого в європейський } \\
\text { і світовий науково-освітній простір спеціаліста ступенядоктора філософіїу галузі знань } 09 \text { «Біологія» } \\
\text { за спеціальністю } 091 \text { «Біологія», здатного до продукування нових ідей, розв’язання комплексних } \\
\text { проблем у галузі, а також самостійної науково-дослідницької, дослідницько-інноваційної, науково- } \\
\text { організаційної, педагогічно-організаційної та практичної діяльності. }\end{array}$} \\
\hline \multicolumn{2}{|c|}{3 - Характеристика освітньої програми } \\
\hline $\begin{array}{l}\text { Предметна область (галузь } \\
\text { знань / спеціальність / } \\
\text { спеціалізація (за наявності)) }\end{array}$ & $\begin{array}{l}\text { Галузь знань: } 09 \text { «Біологія» } \\
\text { Спеціальність: } 091 \text { «Біологія» }\end{array}$ \\
\hline Орієнтація освітньої програми & Освітньо-наукова програма, дослідницько-інноваційна \\
\hline $\begin{array}{l}\text { Основний фокус освітньої } \\
\text { програми та спеціалізації }\end{array}$ & $\begin{array}{l}\text { Розвиток теорії і практики епідеміології інфекційних } \\
\text { захворювань, генетичних порушень людини, стратегії } \\
\text { та методології клінічної лабораторної, мікробіологічної } \\
\text { діагностики, верифікації спадкових захворювань і найбільш } \\
\text { розповсюджених хронічних захворювань людини зі спадковою } \\
\text { схильністю, обгрунтування вибору методу лікування } \\
\text { генетичних захворювань із урахуванням різного ступеню }\end{array}$ \\
\hline
\end{tabular}




\begin{tabular}{|c|c|}
\hline & $\begin{array}{l}\text { спадкової схильності, наукове обгрунтування та організація } \\
\text { мікробіологічного та генетичного моніторингу, створення } \\
\text { нових технологій діагностики та лікування. Систематизація } \\
\text { та структуризація біологічної інформації. Створення сучасних } \\
\text { біотехнологій, у тому числі інформаційних, що сприяють } \\
\text { збереженню та відновленню здоров’я людини. }\end{array}$ \\
\hline $\begin{array}{l}\text { Особливості освітньої } \\
\text { програми }\end{array}$ & $\begin{array}{l}\text { Реалізується у наукових групах, активних у широкому колі } \\
\text { досліджень, що ведуться в галузі біології, у тому числі } \\
\text { впровадження технологій раннього виявлення та профілактики } \\
\text { захворювань, створення онтологічних моделей. }\end{array}$ \\
\hline \multicolumn{2}{|c|}{$\begin{array}{c}4 \text { - Придатність випускників до працевлаштування } \\
\text { та подальшого навчання }\end{array}$} \\
\hline $\begin{array}{l}\text { Придатність до } \\
\text { працевлаштування }\end{array}$ & $\begin{array}{l}\text { Робочі місця у науково-дослідних установах, галузевих } \\
\text { установах різних відомств, закладах охорони здоров’я, } \\
\text { менеджмент та адміністрування у галузях біології та охорони } \\
\text { здоров’я, викладання у закладах вищої освіти, самостійне } \\
\text { працевлаштування. }\end{array}$ \\
\hline Подальше навчання & $\begin{array}{l}\text { Можлива подальша підготовка на четвертому (науковому) рівні } \\
\text { вищої освіти. }\end{array}$ \\
\hline \multicolumn{2}{|r|}{5 - Викладання та оцінювання } \\
\hline Викладання та навчання & 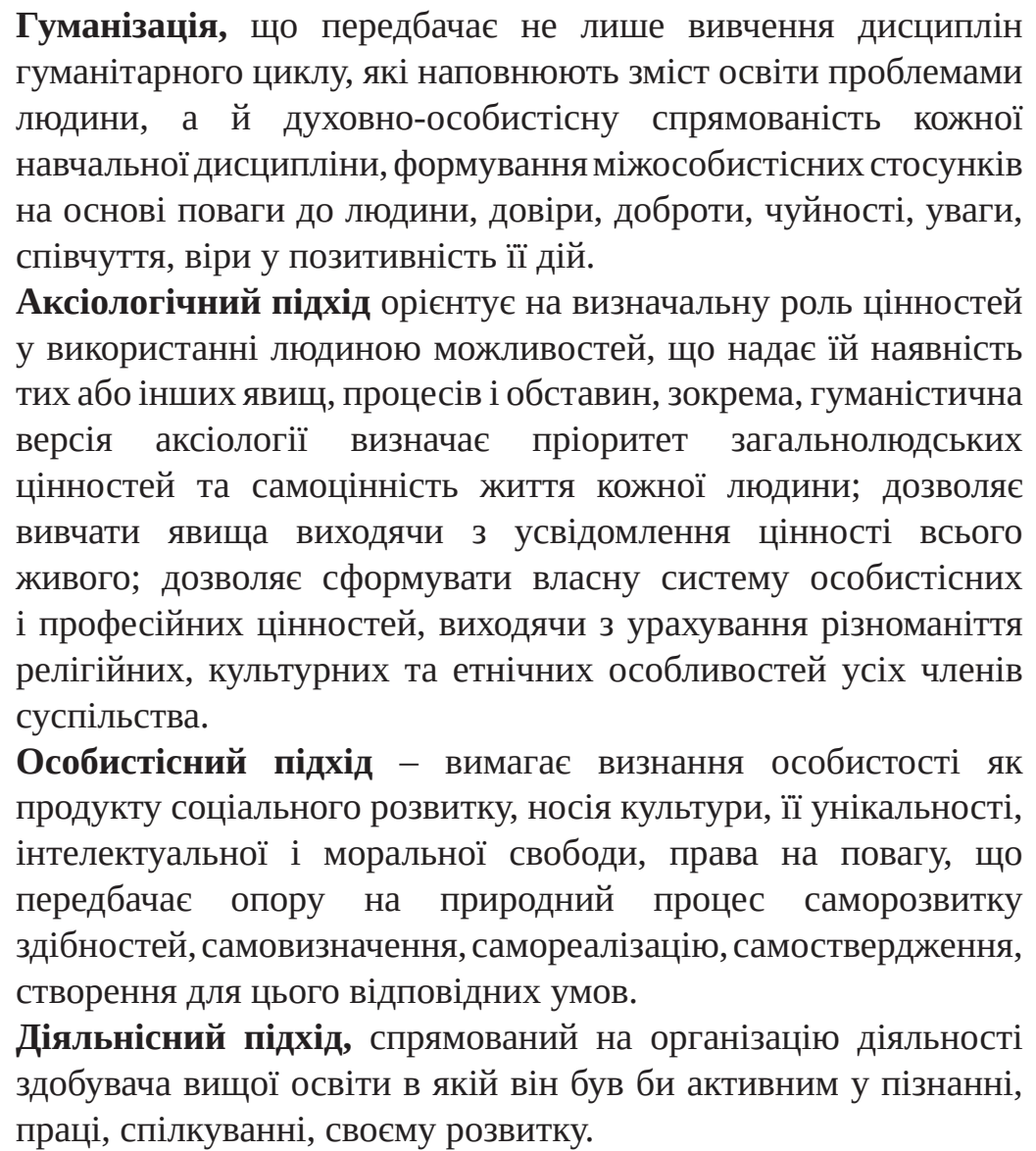 \\
\hline
\end{tabular}




\begin{tabular}{|c|c|}
\hline & $\begin{array}{l}\text { Ресурсний підхід - ставить питання про організацію навчання, } \\
\text { орієнтованого на пошук і розвиток потенціальних можливос- } \\
\text { тей кожного здобувача вищої освіти. } \\
\text { Системний підхід - орієнтує на цілісне та послідовне дослі- } \\
\text { дження явищ і процесів як сутнісно взаємопов’язаних, струк- } \\
\text { турно організованих у стійку динамічну єдність, здатну само- } \\
\text { відтворюватися в умовах зовнішніх викликів. } \\
\text { Синергетичний підхід, провідним принципом якого є самоор- } \\
\text { ганізація та саморозвиток, що здійснюються на основі постій- } \\
\text { ної активної взаємодії цих систем із зовнішнім середовищем } \\
\text { і веде до змін, становлення нових якостей. } \\
\text { Компетентністний підхід передбачає аксіологічну, мотивацій- } \\
\text { ну, рефлексивну, когнітивну, операційно-технологічну та інші } \\
\text { складові результатів навчання, що відображують примноження } \\
\text { не лише знань, умінь і навиків, а й досвіду емоційно-ціннісного } \\
\text { ставлення. } \\
\text { На початку тісне наукове керівництво, підтримка наукового ке- } \\
\text { рівника, підтримка та консультування з боку колег із наукової } \\
\text { групи. Вивчення наукової методології на основі різноманітних } \\
\text { інтерактивних ресурсів, що пропонуються здобувачу вищої } \\
\text { освіти. Лекційні курси, семінари, консультації, самопідготовка } \\
\text { у бібліотеці та на основі інтелекту, індивідуальні консультації. }\end{array}$ \\
\hline Оцінювання & $\begin{array}{l}\text { Різні форми проміжного та заключного контролю на етапах } \\
\text { вивчення дисциплін освітньо-наукової програми (залік, есе, } \\
\text { опитування, комп’ютерне тестування, захист самостійних про- } \\
\text { єктів і рефератів, контрольні роботи). Наукові публікації та ви- } \\
\text { ступи на наукових форумах. Наукові звіти з оцінюванням до- } \\
\text { сягнутого. Моніторинг виконання індивідуального плану та } \\
\text { академічної успішності на всіх рівнях (науковим керівником / } \\
\text { керівниками, колективом кафедри, вченою радою факультету), } \\
\text { атестація. Захист дисертаційної роботи відповідно до чинних } \\
\text { нормативних вимог. }\end{array}$ \\
\hline \multicolumn{2}{|r|}{6 - Програмні компетентності } \\
\hline Інтегральна компетентність (IK) & $\begin{array}{l}\text { Здатність розв’язувати комплексні проблеми в області } \\
\text { професійної діяльності за спеціальністю «Біологія» в галузі } \\
\text { знань біологія; проводити оригінальне наукове дослідження; } \\
\text { інтегрувати отриманні данні та інформацію; будувати } \\
\text { концептуальні, структурні та математичні моделі; оволодіння } \\
\text { методологією науково-педагогічної діяльності; здійснювати } \\
\text { дослідницько-інноваційну діяльність у галузі біологія на основі } \\
\text { глибокого переосмислення наявних і створення нових цілісних } \\
\text { знань та/або професійної практики. }\end{array}$ \\
\hline Загальні компетентності (ЗК) & $\begin{array}{l}\text { 3К1. Дослідницькі компетентності } \\
\text { - Здатність до абстрактного мислення, синтезу, аналізу } \\
\text { та оцінювання сучасних наукових досягнень, генерування } \\
\text { нових знань при вирішенні дослідницьких і практичних зав- } \\
\text { дань; }\end{array}$ \\
\hline
\end{tabular}


- Здатність до самостійного проведення наукового та патентного пошуку з використанням сучасних технологій контентаналізу та колокейт-аналізу, створення власних баз даних;

- Здатність до проведення наукового дослідження в природничих науках із урахуванням сучасних філософських знань, філософської антропології, філософії науки, біоетики, етики біомедичних досліджень;

- Здатність до оцінювання результатів наукових досліджень із використанням знань та вмінь в області біологічної інформатики, поглибленого статистичного аналізу даних;

- Здатність застосовувати сучасні інформаційні технологій у науковій діяльності, організації та проведенні навчальних занять;

- Здатність до управління науковими проєктами, складання пропозицій про фінансування наукових досліджень, реєстрації прав інтелектуальної власності;

- Здатність до набуття універсальних навиків дослідника, зокрема усної та письмової презентації результатів власного наукового дослідження державною мовою з застосуванням сучасних світоглядних і філософських знань.

\section{3К2. Мовні компетентності}

- Здатність представляти та обговорювати наукові результати, вести наукову дискусію державною та іноземною мовами в усній і письмовій формі, володіти науковою термінологію; - Здатність до повного розуміння іншомовних наукових текстів у галузі біологія та вільного письмового викладення наукового тексту іноземною мовою.

\section{3КЗ. Комунікативні компетентності}

- Здатність ефективно застосовувати навики риторики, спілкуватися зі спеціальною та загальною аудиторіями державною та іноземною мовами;

- Здатність представляти складну інформацію в зручний і зрозумілий спосіб усно та письмово, використовуючи відповідну технічну лексику та методи;

- Готовність цінувати та поважати різноманітність та мультикультурність;

- Здатність до ведення наукової дискусії, спілкування з рецензентами, широкою академічною спільнотою та з суспільством у цілому в сфері їх компетентності.

3K4. Робота в групових проєктах

- отовність брати участь у роботі українських і міжнародних дослідницьких колективів для вирішення наукових і науковоосвітніх завдань;

- Здатність працювати у великій науковій групі, розуміючи відповідальність за результати роботи, а також беручи до уваги бюджетні витрати та персональні зобов’язання;

- Спроможність до наукового керівництва, управління проєктами, здатність викладати та передавати знання у наукових групах. 


\section{3К5. Управлінські компетентності}

- Готовність організувати роботу колективу в розв'язанні актуальних проблем біології;

- Здатність працювати в умовах обмеженого часу та ресурсів, а також мотивувати та управляти роботою інших для досягнення поставлених цілей.

3К6. Загальнонаукові (філософські) компетентності

- Здатність до абстрактного мислення, аналізу та синтезу;

- Здатність здійснювати критичний аналіз філософських та наукових засад теоретичної та практичної діяльності в природничих науках у контексті цінностей сучасної науки та загальнолюдських цінностей;

- Здатність засвоювати та розвивати філософську культуру мислення, світоглядні уявлення про загальнонаукові, філософські, соціокультурні засади гуманітарного та природничого знання; - Здатність усвідомлювати рівні можливості та гендерні проблеми, розуміти сучасні ідеї філософії гендеру;

- Здатність застосовувати цінності та принципи біоетики під час планування та проведення наукових досліджень.

\section{3К7. Викладацькі компетентності}

- Здатність педагогічно мислити: діагностувати педагогічні явища, аналізувати їх складові, знаходити способи оптимального вирішення педагогічних проблем;

- Здатність до конкретизації педагогічного прогнозування в планах навчання та виховання, обгрунтування способів та етапів їх реалізації;

- Здатність до рефлексії (уміння аналізувати свою професійну діяльність);

- Здатність працювати в сучасних середовищах передавання знань (системах навчання) та застосовувати сучасні педагогічні системи навчання.

\section{ЗК8. Особистісні компетентності}

- Здатність планувати та вирішувати завдання власного професійного та особистісного розвитку;

- Здатність працювати автономно;

- Здатність бути критичним і самокритичним;

- Здатність генерувати нові ідеї та концепції (креативність), використовувати технології наукової творчості;

- Здатність до лідерства та розвитку лідерських якостей.

\section{ЗК9. Етичні зобов'язання}

- Здатність слідувати етико-правовим нормам та моральним цінностям, принципам етики та біоетики у професійній діяльності, під час планування та проведення наукових досліджень;

- Здатність слідувати принципам академічної доброчесності під час планування, проведення, аналізу та публікації результатів наукового дослідження;

- Здатність здійснювати теоретичну та практичну діяльність в області природничих наук на основі сучасної етики науки, 


\begin{tabular}{|c|c|}
\hline & $\begin{array}{l}\text { принципів і цінностей біоетики, етики біомедичних досліджень } \\
\text { та загальнолюдських цінностей; } \\
\text { - Здатність діяти соціально відповідально та громадянсько } \\
\text { свідомо, прагнути до збереження навколишнього середовища. }\end{array}$ \\
\hline \multirow[t]{5}{*}{$\begin{array}{l}\text { Спеціальні (фахові, професійні) } \\
\text { компетентності (СK) }\end{array}$} & 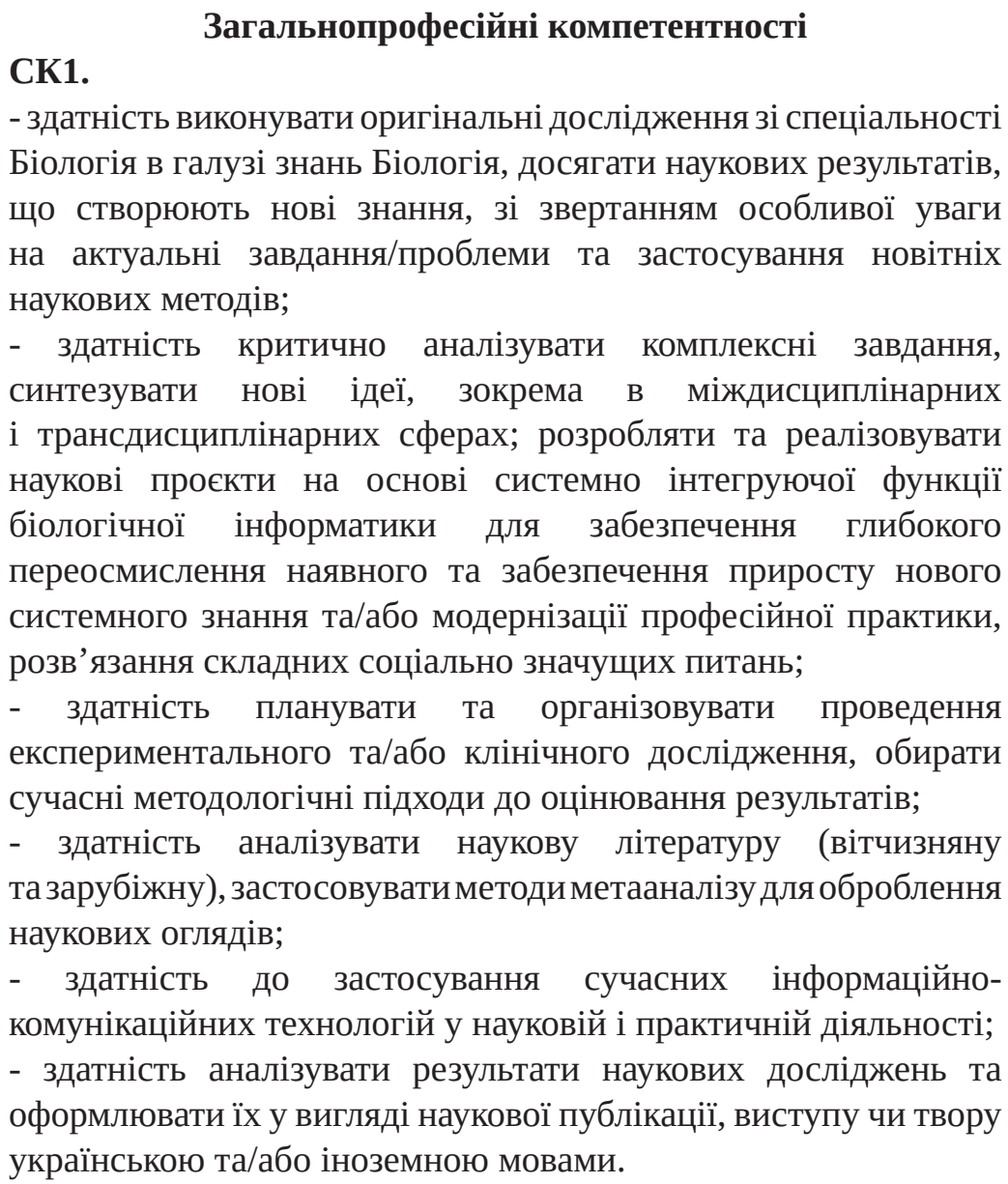 \\
\hline & $\begin{array}{l}\text { Спеціалізовано-професійні компетентності } \\
\text { СК2. Здатність застосовувати знання фундаментальних основ, } \\
\text { сучасних досліджень, проблем і тенденцій із спеціальності } \\
\text { Біологія в галузі Біологія в комплексному аналізі явищ } \\
\text { і процесів, що виникають в Україні та у світі в цілому. }\end{array}$ \\
\hline & $\begin{array}{l}\text { СКЗ. Здатність відокремлювати структурні елементи, що } \\
\text { складають теоретичну та емпіричну основу системи знань } \\
\text { зі спеціальності Біологія. }\end{array}$ \\
\hline & $\begin{array}{l}\text { CK4. Здатність використовуючи знання про людину, iї органи } \\
\text { та системи для постановки мікробіологічного, лабораторного, } \\
\text { клінічного, генетичного заключення шляхом співставлення } \\
\text { зі стандартами, дотримуючись відповідних етичних } \\
\text { і юридичних норм, шляхом прийняття обгрунтованого рішення. }\end{array}$ \\
\hline & $\begin{array}{l}\text { CK5.Здатністьдовиборутаволодіннясучаснимилабораторними, } \\
\text { мікробіологічними, молекулярно-генетичними, біохімічними, } \\
\text { цитогенетичними методами, що дозволяють підтвердження } \\
\text { або скасування попереднього та встановлення остаточного } \\
\text { клінічного діагнозу основних інфекційних, генетичних, }\end{array}$ \\
\hline
\end{tabular}


соматичних захворювань; діагностування невідкладних станів; планування та проведення заходів профілактики інфекційних, генетичних захворювань серед населення; оцінювання результатів досліджень.

CK6. Здатність до визначення методології та принципів діагностики інфекційних, загально-соматичних, спадкових захворювань і хвороб із мультифакторним типом успадкування.

CK7. Здатність в умовах науково-дослідної установи / закладу охорони здоров'я, використовуючи статистичні та лабораторні методи, здійснювати епідеміологічний аналіз, у т. ч. інфекційної захворюваності населення, виявляючи: групи ризику; території ризику; час ризику; фактори ризику.

СК8. Здатність на підставі даних про стан здоров'я певних контингентів населення та про наявність впливу на нього навколишнього середовища, використовуючи існуючі методи, здійснювати систему санітарно-гігієнічних, профілактичних заходів, пропаганди здорового способу життя.

СК9. Здатність до використання уніфікованих автоматизованих баз даних медико-біологічного/фармацевтичного профілю.

CK10. Здатність створювати сучасні біологічні інформаційні продукти, в тому числі використовуючи сервіси мережі Інтернет, сучасні інформаційні технології та системи, технології «Big Data».

CK11. Здатність аналізувати закономірності функціонування окремих органів і систем, фундаментальних біологічних уявлень, основних теорій, концепцій i принципів для постановки та рішення нових завдань при впровадженні нових методів дослідження та обладнання.

CK12. Здатність здійснювати науково-педагогічну діяльність у закладах вищої освіти.

CК13. Здатність прогнозувати науково обгрунтовані підходи до модернізації вітчизняної системи охорони здоров’я, організовувати та забезпечувати процеси управлінської діяльності.

CK14. Здатність до розроблення та застосування правил опису семантичних одиниць повідомлень, кодування повідомлень; забезпечення заходів виробничої безпеки. 


\section{7 - Програмні результати навчання}

\begin{tabular}{|c|c|}
\hline ПРН1 & $\begin{array}{l}\text { Здобуття знань і розумінь у розв’язанні наукових проблем у галузі знань } 09 \text { «Біологіяя } \\
\text { та спеціальності } 091 \text { «Біологія» шляхом застосування комплексу сучасних } \\
\text { інструментарію, методик і методів досліджень; критичне осмислення відповідних } \\
\text { проблем наявних у галузі; рівень знань повинен бути достатнім для проведенн } \\
\text { самостійних наукових досліджень на рівні світових досягнень. }\end{array}$ \\
\hline
\end{tabular}

Здатність до промоції нових знань в академічному та професійному контексті, впровадження технологічних, соціальних і культурних здобутків у суспільство, ПРН2 зокрема готовність до підготовки, проведення та участі в наукових заходах, оприлюднення результатів наукових досліджень зі спеціальності в зарубіжних і затверджених МОН України наукових фахових виданнях.

\begin{tabular}{|l|l|}
\hline ПРН3 & $\begin{array}{l}\text { Здатність здійснювати інформаційний пошук і роботу з бібліотечними ресурсами, } \\
\text { базами даних і знань, іншими онлайн ресурсами, підготовку аплікацій для подання } \\
\text { на отримання грантів за обраною тематикою наукового дослідження зі спеціальності. }\end{array}$ \\
\hline ПРН4 & $\begin{array}{l}\text { Здатність розроблення наукового проєкту відповідно до завдань дисертаційного } \\
\text { дослідження; складання пропозицій із фінансування наукових досліджень у галузі. }\end{array}$ \\
\hline
\end{tabular}

Здатність здійснювати оброблення та інтерпретацію отриманих експериментальних

\begin{tabular}{l|l} 
ПРН5 & $\begin{array}{l}\text { i емпіричних даних, використовувати сучасні математичні та статистичні методи } \\
\text { при обробленні даних наукових досліджень. }\end{array}$ \\
\hline
\end{tabular}

Здатність застосовувати філософські знання у теорії та практиці; здатність до

ПРН6 абстрактного мислення, аналізу та синтезу, до здійснення пошукової (евристичної) діяльності, дослідження пріоритетних напрямів розвитку спеціальності, організації та проведення наукових досліджень із сучасних проблем.

\begin{tabular}{|c|c|}
\hline ПРН7 & $\begin{array}{l}\text { Здатність підготувати та успішно захистити дисертаційну роботу зі спеціальності } \\
\text { Біологія на основі власних досліджень, а також використовувати (та визнат) } \\
\text { результати роботи інших членів наукової групи. }\end{array}$ \\
\hline ПРН8 & $\begin{array}{l}\text { Здатність до усвідомлення мовних норм, що склалися історично в фонетиці, лексиці, } \\
\text { граматиці, орфоепії, семантиці, стилістиці та адекватне їх застосування в предметній } \\
\text { області галузі та спеціальності в процесі використання державної чи іноземної мови. }\end{array}$ \\
\hline ПРН9 & $\begin{array}{l}\text { Здатність до проведення вербального та невербального спілкування, спостереження, } \\
\text { вислуховування, постановки запитань, здатність вести співбесіду з різними групами } \\
\text { співрозмовників, проведення та участь у зборах. }\end{array}$ \\
\hline ПРН10 & $\begin{array}{l}\text { Здатність адекватно та доречно практично користуватися мовою в конкретних } \\
\text { ситуаціях (висловлюватисвоїдумки,бажання, наміри,проханнятощо),встановлювати } \\
\text { та підтримувати необхідні контакти з іншими людьми, використовувати для цього як } \\
\text { мовні, так і позамовні та інтонаційні засоби виразності мовлення. }\end{array}$ \\
\hline
\end{tabular}




\begin{tabular}{|c|c|}
\hline ПРН11 & $\begin{array}{l}\text { Формування системи знань зі спеціальності, використовуючи унікальні дані, } \\
\text { обгрунтовані рішення, нові інтерпретації, інноваційні методи, за допомогою } \\
\text { оригінальних досліджень і прогресивних учень. }\end{array}$ \\
\hline ПРН12 & $\begin{array}{l}\text { Уміння на теоретичному рівні генерувати ідеї, гіпотези наукового дослідження, } \\
\text { розробляти доказову базу, визначати закономірності; розуміти та будувати } \\
\text { міждисциплінарні зв’язки між природничими та гуманітарними науками. }\end{array}$ \\
\hline ПРН13 & $\begin{array}{l}\text { Здатність слідувати етико-правовим нормам і моральним цінностям, принципам } \\
\text { біоетики у професійній діяльності, дотримуватись принципів академічної } \\
\text { доброчесності. }\end{array}$ \\
\hline ПРН14 & $\begin{array}{l}\text { Уміння використовувати сучасні дані, накопичені в результаті наукових досліджень, } \\
\text { застосовувати знання, отримані та відібрані в ході експериментальних досліджень } \\
\text { іпрактичноїдіяльності зі спеціальності, для визначення ефективності, систематизації, } \\
\text { узагальнення та пояснення. }\end{array}$ \\
\hline ПРН15 & $\begin{array}{l}\text { Здатність до розроблення, організації та впровадження профілактичних } \\
\text { і реабілітаційних стратегій на основі особистих досліджень та авторських методик } \\
\text { при створенні та реалізації індивідуального плану з метою покращення здоров’я, } \\
\text { функціональних можливостей, адаптації до оточуючих умов, підвищення рівня } \\
\text { здоров’я населення. }\end{array}$ \\
\hline ПРН16 & $\begin{array}{l}\text { Здатність розуміти загальні принципи та методи біологічних наук, а також } \\
\text { методологію наукових досліджень, застосувати їх у власних дослідженнях у галузі } \\
\text { біології та у педагогічній практиці. }\end{array}$ \\
\hline ПРН17 & $\begin{array}{l}\text { Здатність спілкуватися з нефахівцями своєї галузі (робота в мультидисциплінарній } \\
\text { команді). Вміння спілкування з людьми з різними психологічними якостями, різного } \\
\text { віку, рівня освіти, соціальної та професійної приналежності. }\end{array}$ \\
\hline ПРН18 & $\begin{array}{l}\text { Здатність до концептуальних і методологічних знань із біології та на межі } \\
\text { предметних областей. Мати дослідницькі навики, достатні для проведення наукових } \\
\text { і прикладних досліджень нарівні світових досягнень, отримання нових знань та/або } \\
\text { здійснення інновацій. }\end{array}$ \\
\hline ПРН19 & $\begin{array}{l}\text { Здатність до аналізу, співставлення, порівняння варіантів розвитку в галузі знань } \\
09 \text { «Біологія» та спеціальності } 091 \text { «Біологія», розв’язання у контексті викликів } \\
\text { XXI ст. }\end{array}$ \\
\hline
\end{tabular}




\section{8 - Ресурсне забезпечення реалізації програми}

Специфічні характеристики $\quad$ Кадрове забезпечення освітнього процесу відповідає
кадрового забезпечення Ліцензійним умовам провадження освітньої діяльності закладу освіти у сфері вищої освіти. Викладання навчальних дисциплін здійснюється науково-педагогічними працівниками з науковим ступенем за профілем спеціальності.

Специфічні характеристики матеріально-технічного

Навчальні лабораторії кафедр, задіяних у здійсненні освітньої забезпечення діяльності за ОНП «Біологія», забезпечені необхідним сучасним обладнанням; науковий навчально-методичний центр дистанційної освіти, центр симуляційних методів навчання 3 кабінетом лабораторної медицини, міжнародний генетичний центр,віварій,науково-досліднийцентр,клінікарепродуктивних технологій, комп'ютерні класи, наукова бібліотека; понад 200 баз, серед яких 18 науково-дослідні інститути НАМН України та 4 установи НАН України, заклади охорони здоров'я різного підпорядкування - партнери різної форми власності, з якими укладено відповідні договори, створюють умови для ефективної та якісної практичної підготовки здобувачів освіти та виконання наукових досліджень.

Специфічні характеристики інформаційного та навчальнометодичного забезпечення
Офіційний веб-сайт НУОЗ України імені П. Л. Шупика: https://nuozu.edu.ua/.

\section{9 - Академічна мобільність}

\begin{tabular}{|l|l|}
\hline $\begin{array}{l}\text { нацедіональна } \\
\text { мобільність }\end{array}$ & $\begin{array}{l}\text { Забезпечується двосторонніми договорами (угодами) між } \\
\text { НУОЗ України імені П. Л. Шупика та ЗВО України / установами } \\
\text { НАН України та НАМН України. }\end{array}$ \\
\hline $\begin{array}{l}\text { Міжнародна } \\
\text { мредитна } \\
\text { мобільність }\end{array}$ & $\begin{array}{l}\text { Забезпечується двосторонніми договорами (угодами) між } \\
\text { НУОЗ України імені П. Л. Шупика та ЗВО країн-партнерів. }\end{array}$ \\
\hline $\begin{array}{l}\text { Навчання іноземних здобувачів } \\
\text { вищої освіти }\end{array}$ & $\begin{array}{l}\text { Навчання іноземних здобувачів вищої освіти здійснюється } \\
\text { на загальних умовах українською. }\end{array}$ \\
\hline
\end{tabular}




\section{2. ПЕРЕЛІК КОМПОНЕНТ ОСВІТНЬОЇ ПРОГРАМИ ТА ЇХ ЛОГІЧНА ПОСЛІДОВНІСТЬ}

\section{1. Розподіл змісту освітньо-наукової програми підготовки доктора філософії}

\begin{tabular}{|c|c|}
\hline Зміст освітньо-наукової програми & $\begin{array}{c}\text { Академічних годин/кредитів } \\
\text { ЄКТС }\end{array}$ \\
\hline $\begin{array}{l}\text { Загальний навчальний час підготовки } \\
\text { (академічних годин/кредитів ЄКТС) } \\
\text { для докторів філософії за спеціальністю } 091 \text { «Біологія» }\end{array}$ & 60 кредитів \\
\hline $\begin{array}{l}\text { Оволодіння загальнонауковими (філософськими) } \\
\text { компетентностями }\end{array}$ & 5 кредитів \\
\hline $\begin{array}{l}\text { Набуття універсальних навиків дослідника: } \\
\text { - } \quad \text { усної і письмової презентації результатів власного } \\
\text { наукового дослідження українською мовою та реєстрації } \\
\text { прав інтелектуальної власності } \\
\text { - } \quad \text { застосування сучасних інформаційних технологій } \\
\text { у науковій діяльності } \\
\text { - } \\
\text { - } \\
\quad \text { організація та проведення навчальних занять } \\
\text { щцодо фінансування наукових досліджень }\end{array}$ & $\begin{array}{c}14 \text { кредитів } \\
2 \text { кредити } \\
\\
5 \text { кредитів } \\
4 \text { кредити } \\
3 \text { кредити }\end{array}$ \\
\hline Здобуття мовних компетентностей & 8 кредитів \\
\hline $\begin{array}{l}\text { Здобуття глибинних знань зі спеціальності, за якою здобувач } \\
\text { вищої освіти проводить дослідження } \\
\text { Асистентська педагогічна практика за спеціальністю }\end{array}$ & $\begin{array}{l}9 \text { кредитів } \\
3 \text { кредити }\end{array}$ \\
\hline $\begin{array}{l}\text { Дисципліни за вибором } \\
\text { (не менше } 25 \text { \% загальної кількості кредитів ЄКТС) }\end{array}$ & 21 кредит \\
\hline
\end{tabular}


2.2. Перелік компонент освітньо-наукової програми

\begin{tabular}{|c|c|c|c|}
\hline $\begin{array}{l}\text { Код } \\
\mathbf{H} / д\end{array}$ & Компоненти освітньої-наукової програми & $\begin{array}{l}\text { Кількість } \\
\text { кредитів }\end{array}$ & $\begin{array}{l}\text { Форма } \\
\text { підсумкового } \\
\text { контролю }\end{array}$ \\
\hline 1 & 2 & 3 & 4 \\
\hline \multicolumn{2}{|c|}{ Загальний обсяг освітньо-наукової програми } & 60 & \\
\hline \multicolumn{4}{|c|}{ Обов’язкові компоненти ОНП } \\
\hline \multicolumn{2}{|c|}{ Загальний обсяг обов’язкових компонент } & 39 & \\
\hline \multicolumn{4}{|c|}{$\begin{array}{c}\text { Оволодіння загальнонауковими (філософськими) компетентностями, } \\
\text { спрямованими на формування системного наукового світогляду, } \\
\text { професійної етики та загального культурного кругозору }\end{array}$} \\
\hline OK1 & $\begin{array}{l}\text { Філософія, сучасна методологія наукових досліджень } \\
\text { і біоетика }\end{array}$ & 5 & залік \\
\hline \multicolumn{4}{|c|}{ Набуття універсальних навиків дослідника } \\
\hline OK2 & $\begin{array}{l}\text { Управління науковими проєктами. } \\
\text { Фінансування наукових досліджень }\end{array}$ & 3 & залік \\
\hline OK3 & $\begin{array}{l}\text { Презентація результатів наукових досліджень. } \\
\text { Реєстрація та захист прав інтелектуальної власності }\end{array}$ & 2 & залік \\
\hline OK4 & $\begin{array}{l}\text { Сучасні інформаційні технології } \\
\text { у науковій діяльності та біостатистика }\end{array}$ & 5 & залік \\
\hline OK5 & $\begin{array}{l}\text { Методологія та організація педагогічного процесу, } \\
\text { проведення навчальних занять і асистентської } \\
\text { педагогічної практики }\end{array}$ & 4 & залік \\
\hline \multicolumn{4}{|c|}{$\begin{array}{c}\text { Набуття мовних компетентностей, достатніх для представлення } \\
\text { та обговорення результатів своєї наукової роботи іноземною мовою } \\
\text { в усній і письмовій формі, а також для повного розуміння } \\
\text { іншомовних наукових програм }\end{array}$} \\
\hline OK6 & Іноземна мова Upper Intermediate & 8 & залік \\
\hline \multicolumn{4}{|c|}{$\begin{array}{c}\text { Здобуття глибинних знань зі спеціальності, } \\
\text { за якою здобувач проводить дослідження }\end{array}$} \\
\hline OK7 & $\begin{array}{l}\text { Курс професійної та практичної підготовки } \\
\text { за спеціальністю }\end{array}$ & 9 & залік \\
\hline OK8 & $\begin{array}{l}\text { Асистентська педагогічна практика } \\
\text { за спеціальністю }\end{array}$ & 3 & залік \\
\hline
\end{tabular}


Вибіркові компоненти ОНП

\begin{tabular}{|c|c|c|c|}
\hline \multicolumn{2}{|c|}{ Загальний обсяг вибіркових компонент } & \multirow{2}{*}{21} & \multirow[b]{2}{*}{4} \\
\hline 1 & 2 & & \\
\hline \multicolumn{4}{|c|}{ Вибіркові дисципліни, спрямовані на набуття загальних компетентностей* } \\
\hline BK9 & Доказова медицина & 3 & залік \\
\hline BK10 & Логіка наукового дослідження та сучасна філософія науки & 3 & залік \\
\hline BK11 & Методологічні та етико-правові засади біомедичних досліджень & 3 & залік \\
\hline BK12 & Математичне моделювання в охороні здоров’я та біології & 3 & залік \\
\hline BK13 & Інформаційні технології пошуку та структуризації інформації & 3 & залік \\
\hline BK14 & $\begin{array}{l}\text { Актуальні питання медичного та фармацевтичного права. Правове } \\
\text { забезпечення досліджень у галузі охорони здоров’я та галузі біології }\end{array}$ & 3 & залік \\
\hline BK15 & $\begin{array}{l}\text { Технології наукової творчості. Основи академічного письма та } \\
\text { риторики }\end{array}$ & 3 & залік \\
\hline BK16 & $\begin{array}{l}\text { Морально-етичні та соціокультурні виміри природничих наук і } \\
\text { біотехнологій }\end{array}$ & 3 & залік \\
\hline BK17 & Системна біомедицина & 3 & залік \\
\hline BK18 & Психологічні механізми науково-дослідної діяльності & 3 & залік \\
\hline BK19 & $\begin{array}{l}\text { Психологічні та правові аспекти конфліктології (у галузі охорони } \\
\text { здоров’я та галузі біологія) }\end{array}$ & 3 & залік \\
\hline \multicolumn{4}{|c|}{ Вибіркові дисципліни, спрямовані на набуття спеціальних компетентностей** } \\
\hline BK20 & $\begin{array}{l}\text { Вибіркові навчальні дисципліни, а також цикли тематичного } \\
\text { удосконалення, стажування, спеціалізації та інші форми неформальної } \\
\text { та інформальної освіти за вибором здобувача вищої освіти (спрямовані } \\
\text { на формування спеціальних компетентностей) }\end{array}$ & 3-15 & залік \\
\hline
\end{tabular}

Примітки: * - здобувач вищої освіти обирає дві дисципліни з кожного тематичного напряму; ** - здобувач вищої освіти обирає одну дисципліну з переліку, представленому на офіційному веб-сайті університету. 


\section{3. СТРУКТУРНО-ЛОГІЧНА СХЕМА ПІДГОТОВКИ ДОКТОРІВ ФІЛОСОФІї}

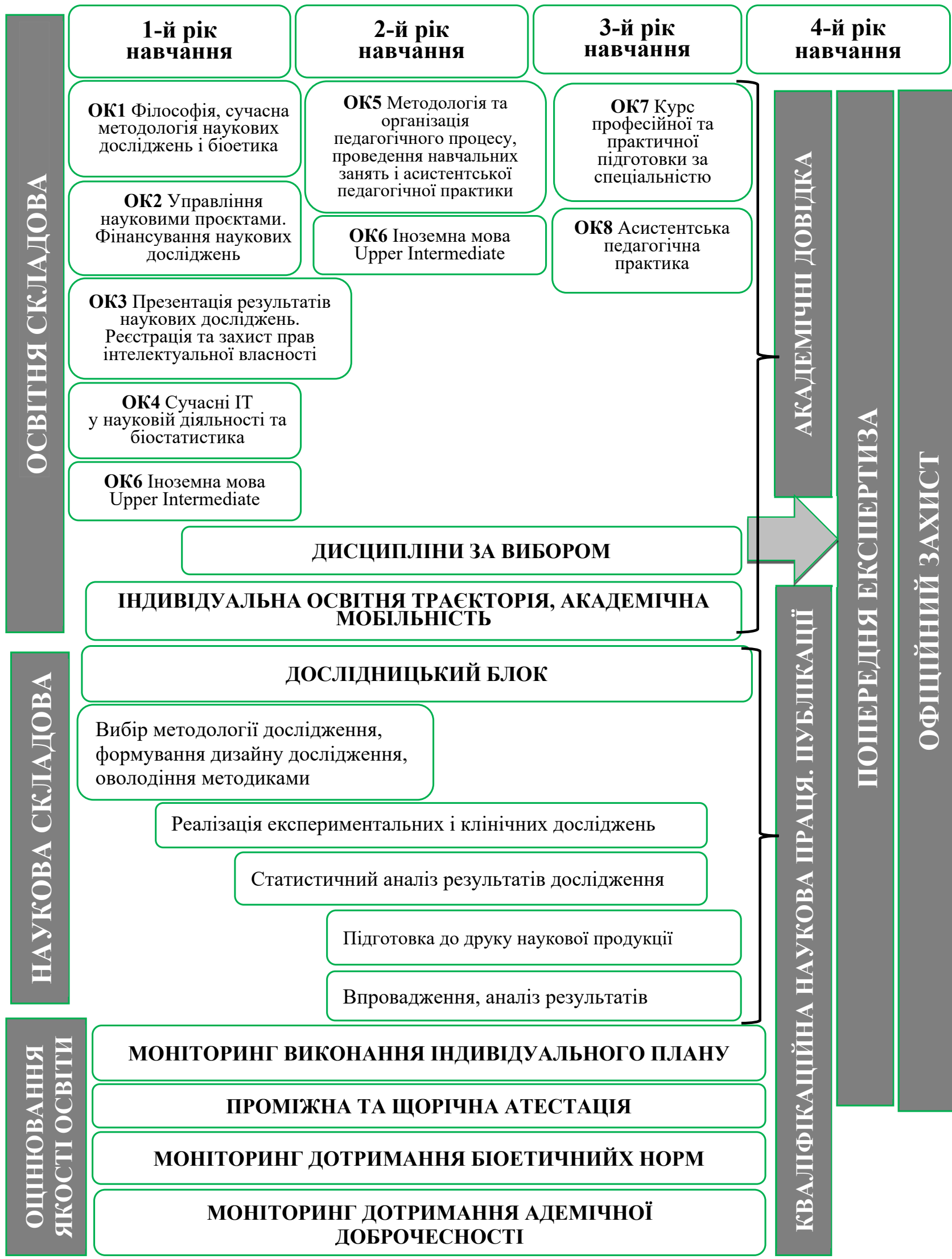




\section{3. ФОРМА АТЕСТАЦІЇ ЗДОБУВАЧІВ ВИЩОЇ ОСВІТИ}

Атестація осіб, які здобувають ступінь доктора філософії, здійснюється постійно діючою або разовою спеціалізованою вченою радою, акредитованою Національним агентством із забезпечення якості вищої освіти, на підставі публічного захисту наукових досягнень у формі кваліфікаційної наукової праці (дисертаційної роботи).

Кваліфікаційна наукова праця на здобуття ступеня доктора філософії є самостійним розгорнутим дослідженням, що пропонує розв'язання актуального наукового завдання в галузі Біології або на її межі та сумісних галузей, результати якого становлять оригінальний внесок у загальну суму біологічних знань та оприлюднені у відповідних публікаціях.
Обов'язковою умовою допуску до захисту $€$ успішне виконання здобувачем його індивідуального навчального плану.

Здобувач ступеня доктора філософії має право на вибір спеціалізованої вченої ради.

Дисертації осіб, які здобувають ступінь доктора філософії, а також відгуки опонентів оприлюднюються на офіційному веб-сайті НУОЗ України імені П. Л. Шупика відповідно до чинного законодавства.

Підсумкова атестація здобувачів вищої освіти, які повністю виконали програму підготовки доктора філософії за спеціальністю 091 «Біологія», завершується присудженням наукового ступеня доктора філософії за спеціальністю 091 «Біологія» з врученням диплому встановленого зразка.

\section{Захист дисертаційної роботи передбачає перевірку програмних результатів навчання:}

Здатність особи розв’язувати комплексні проблеми в галузі професійної та/або дослідницько-інноваційної діяльності, що передбачає глибоке переосмислення наявних і створення нових цілісних знань та/або професійної практики

\section{Знання.}

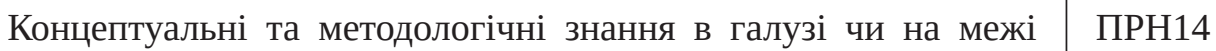
галузей знань або професійної діяльності.

\section{Уміння/навики.}

Спеціалізовані уміння/навики і методи, необхідні для розв’язання значущих проблем у сфері професійної діяльності, науки та/або інновацій, розширення та переоцінки вже існуючих знань і професійної практики.

Започаткування, планування, реалізація та коригування послідовного процесу грунтовного наукового дослідження з дотриманням належної академічної доброчесності.

Критичний аналіз, оцінювання та синтез нових і комплексних ідей.

ПРН1; ПРН5

\section{Комунікація.}

Вільне спілкування з питань, що стосуються сфери наукових

ПРН2; ПРН9; ПРН10; ПРН17

та експертних знань, з колегами, широкою науковою

спільнотою, суспільством у цілому.

Використання академічної української та іноземної мови у професійній діяльності та дослідженнях.

\section{Відповідальність і автономія}

Демонстрація значної авторитетності, інноваційність, високий ступінь самостійності, академічна та професійна доброчесність, послідовна відданість розвитку нових ідей або процесів у передових контекстах професійної та наукової діяльності.

Здатність до безперервного саморозвитку та самовдосконалення.

ПРН3; ПРН4; ПРН13

ПРН1

ПРН2; ПРН8; ПРН9; ПРН10; ПРН17

ПРН6; ПРН7; ПРН12; ПРН15; ПРН16; ПРН18; ПРН19

ПРН11 


\section{Система внутрішнього забезпечення якості вищої освіти}

Система внутрішнього забезпечення якості вищої освіти НУОЗ України імені П. Л. Шупика складається з процедур і заходів, передбачених Законами України «Про освіту» та «Про вищу освіту».

\section{4. МАТРИЦЯ ВІДПОВІДНОСТІ ПРОГРАМНИХ КОМПЕТЕНТНОСТЕЙ КОМПОНЕНТАМ ОСВІТНЬОЇ ПРОГРАМИ}

\begin{tabular}{|c|c|c|c|c|c|c|c|c|c|c|c|c|c|c|c|c|c|c|c|c|}
\hline & 름 & $\frac{7}{0}$ & $\frac{n}{0}$ & $\frac{ \pm}{0}$ & $\frac{12}{0}$ & $\frac{0}{0}$ & $\frac{1}{0}$ & $\begin{array}{l}\infty \\
0 \\
0\end{array}$ & صి & $\frac{}{}$ & $\underset{7}{ }$ & $\frac{\mathcal{H}}{\oplus}$ & $\frac{n}{\frac{n}{n}}$ & $\frac{\Xi}{\frac{\Delta}{n}}$ & $\frac{n}{\not}$ & $\frac{\bullet}{\frac{1}{n}}$ & $\frac{N}{\bar{n}}$ & $\frac{\infty}{\stackrel{n}{n}}$ & $\frac{\sigma}{\frac{\pi}{n}}$ & $\frac{\text { Nิ}}{n}$ \\
\hline 3K1 & + & + & + & + & & + & + & + & + & + & + & + & + & + & + & + & + & & & + \\
\hline 3K2 & & + & & + & + & + & + & + & & & & & & & & & + & + & + & + \\
\hline 3K3 & + & + & & + & + & + & + & + & & + & + & & & & & & + & + & + & \\
\hline 3K4 & & + & + & + & + & & + & & & & & & + & & + & + & + & + & + & \\
\hline 3K5 & & & + & + & + & & & & & & & & & + & + & + & & + & + & \\
\hline 3К6 & + & + & & & & & & & + & + & + & + & & & & & + & & & \\
\hline 3K7 & & & & & + & + & & + & & & & & & & & + & & + & & \\
\hline 3K8 & + & & & & + & & + & & + & + & + & + & & + & & & & + & + & + \\
\hline ЗК9 & + & & & & & & + & & & & + & + & + & & & & + & & & \\
\hline CK1 & + & + & + & + & & + & + & & & + & + & + & + & + & + & + & + & + & & + \\
\hline CK2 & + & + & & & & + & + & + & & + & & & & & + & & & & & + \\
\hline CK3 & + & & & & + & + & & + & + & & & + & & & + & & & & & + \\
\hline CK4 & + & & & & & + & + & + & & & + & + & + & + & + & + & + & & & + \\
\hline CK5 & & & & & & & + & + & & & & & + & & + & & + & & & + \\
\hline CK6 & & & & & & & + & + & & & & & + & & + & & & & & + \\
\hline CK7 & & & + & & & & + & + & & & & & + & + & & & & & & + \\
\hline СК8 & & & + & + & & & + & & & & & & + & & & & + & & & + \\
\hline CK9 & & & + & & & & + & + & & & & & + & + & & + & & & & + \\
\hline CK10 & & & + & & & & + & + & & & & & & & + & + & & & & + \\
\hline CK11 & & & & & & + & & + & + & + & & + & & & & + & & & & + \\
\hline CK12 & & & & & + & & & + & & & & & & & & + & & & & + \\
\hline CK13 & & & & + & & & + & & & & & & & & & & + & & & + \\
\hline CK14 & & & + & & & & + & + & & & & & & & + & & + & & & + \\
\hline
\end{tabular}


5. МАТРИЦЯ ЗАБЕЗПЕЧЕННЯ ПРОГРАМНИХ РЕЗУЛЬТАТІВ НАВЧАННЯ ВІДПОВІДНИМИ КОМПОНЕНТАМИ ОСВІТНЬОЇ ПРОГРАМИ

\begin{tabular}{|c|c|c|c|c|c|c|c|c|c|c|c|c|c|c|c|c|c|c|c|c|}
\hline & $\frac{7}{0}$ & $\frac{\vartheta}{0}$ & $\frac{n}{0}$ & $\frac{ \pm}{0}$ & $\frac{10}{0}$ & $\frac{0}{0}$ & $\frac{1}{0}$ & $\stackrel{\infty}{a}$ & $\stackrel{\theta}{\mathscr{1}}$ & $\frac{}{\frac{1}{n}}$ & $\underset{ }{ㅋ}$ & $\frac{\mathscr{N}}{\mathscr{2}}$ & $\frac{m}{\ddot{n}}$ & $\frac{ \pm}{\nexists}$ & $\frac{10}{ㅁ}$ & $\frac{\theta}{\mathscr{n}}$ & $\frac{\widehat{N}}{\bar{\theta}}$ & $\frac{\infty}{\not}$ & $\frac{\sigma}{\ddot{\theta}}$ & ำ \\
\hline ПРН1 & + & + & + & + & & + & + & & + & + & + & & + & + & + & + & + & & & + \\
\hline ПРН2 & + & + & & + & + & & + & + & & + & & & & + & & + & + & + & + & \\
\hline ПРНЗ & & & + & + & & + & + & & & & & + & + & + & & & + & & & + \\
\hline ПРН4 & & & + & + & & & + & & & & & + & + & & & & & & & \\
\hline ПРН5 & & & + & + & & & + & & & & & + & + & + & & & & & & + \\
\hline ПРН6 & + & & + & & & + & + & & + & & + & + & & + & + & & & & & + \\
\hline ПРН7 & + & + & + & + & & + & + & & & + & & & & + & & + & + & + & & + \\
\hline ПРН8 & & + & & & & + & + & + & & & & & & & & & & & & + \\
\hline ПРН9 & & + & & & + & & + & + & & & & & & & & & & + & + & \\
\hline ПРН10 & & & & + & + & + & + & + & & + & & & & + & & & & + & + & \\
\hline ПРН11 & & & & + & + & & + & + & & & & & & + & + & & & & & + \\
\hline ПРН12 & + & & & & & & + & + & + & & + & & & + & + & & & & & \\
\hline ПРН13 & + & & & & & & + & & & & & + & & & & & & & & + \\
\hline ПРН14 & & + & & & + & + & & + & + & & + & + & + & & + & & & & & + \\
\hline ПРН15 & & & & & & & + & + & & + & & & & + & + & + & & & & + \\
\hline ПРН16 & + & & & & + & & + & + & & & & + & + & + & + & & & + & + & + \\
\hline ПРН17 & & + & & & + & + & & + & & & & & + & & & & + & + & + & + \\
\hline ПРН18 & + & & & & & & + & + & + & & & & & & + & + & & & & + \\
\hline ПРН19 & + & + & + & & & & + & & + & & & & & & + & & & & & + \\
\hline
\end{tabular}

